\title{
THE BANKING SECTOR PRODUCT INNOVATIONS - GEARING FACTORS FOR CUSTOMER CONFIDENCE
}

\author{
T. Yosifov ${ }^{1 *}$, T. Dimitrova ${ }^{2}$ \\ Department of Finance, Faculty of Economic and Social Sciences, Plovdiv University "Paisii \\ Hilendarski”, Plovdiv, Bulgaria \\ Department of Marketing and International Economic Relations, Faculty of Economic and Social \\ Sciences \\ Plovdiv University “Paisii Hilendarski”, Plovdiv, Bulgaria
}

\begin{abstract}
There are many up-to-date issues on the access to bank crediting within Bulgaria and these issues are various by nature. On the one hand, we may witness the low degree of bankers' confidence of the market environment of the Bulgarian enterprises; on the other hand, the bank confidence of market players seems to be impaired.

The aim of this paper is to identify "the bottleneck" within the market relation "banks -customers of bank services". Problem identification shall be utilized to analyze the challenges to eliminate the bottleneck controversy of the investigated market relation.

The authors stand on the position that use of product innovations within the banking sector is a subject to marketing approaches, which may be utilized to gear the inter-bank competition - which is one of the main challenges to ease credit terms.
\end{abstract}

Key words: Bank sector, product innovations, bank confidence.

\section{INTRODUCTION}

Improving credit availability in Bulgaria is an issue of great importance and concern that has become particularly pressing in the years that followed its accession in the EU. Credit availability for Bulgarian companies which have since then been operating under the conditions of increasing external and internal competition, is often a prerequisite for normal business functioning. This is even more so due to the fact that there are practically no sufficient alternative options for provision of external finance. While not all local businesses are growth-oriented, at a certain stage of their development, they need capital which has a strong positive impact on their competitiveness and adaptability to the new market conditions. The purpose of this article is to highlight the major weaknesses in the

\footnotetext{
*Correspondence to: Trayan Yosifov, Department of Finance, Faculty of Economic and Social Sciences, Plovdiv University "Paisii Hilendarski", Plovdiv 4000, Bulgaria., 24 Tsar Asen St., GSM:, +359899309613,E-mail: t_yosifov@abv.bg
}

relationship "banks - customers" and to outline, respectively, the preconditions for their efficient improvement.

\section{Confidence as a key factor for bank financing demand and supply.}

Improving the conditions and the activation of credit availability on behalf of the banks in Bulgaria is an issue of great importance and practical significance. This is particularly pressing over the last few years with the growing belief that the causes of the most severe economic crisis since the Great Depression are rooted in the erroneous model of relations between market participants and financial institutions. In this connection, J. Stiglitz wrote 'Make no mistake: we are witnessing the biggest crisis since the Great Depression. In some ways it is worse than the Great Depression, because the latter did not involve complicated instruments - the derivatives, for example, and we did not have anything close to the magnitude of today's cross border finance' (5).

Undoubtedly, confidence and trust which market participants have in both the markets 
YOSIFOV T., et al.

(as mid-term expectations usually form the current behaviour related with consumer and investment choice) and the bank institutions play a crucial role.

Historical development has proved the correlation between system confidence and loan supply. Evidence to sustain the latter is the deposit base of our country which has been growing steadily since the outset of the financial-economic crisis in 2008. Obviously, the prevailing opinion is that bank deposits and savings schemes give safe return, albeit limited, unlike stagnant markets with high levels of investment and market risk. This is illustrative of the high credence in the Bulgarian bank system but also reflects the general pessimistic attitude and expectancy of society that heightens the need of assuming greater responsibility on the part of the commercial banks in terms of customer service and increasing credit availability in particular. Here, it is important to remind the great responsibility of banks in the conditions of market economy to undergo constant technological renovation, develop and provide innovative products and services.

The confidence in the environment and the expectations of the business assumed by analysts as one of the essential indicators of the economic condition and perspectives has plummeted. Similar trend is detected by the National Statistical Institute for the period 2006-2014 when consumer confidence is measured by negative values (Table 1). Furthermore, data shows that the general consumer distrust widens from the beginning of 2010 almost to the end the relevant period.

Table 1. Consumer Survey

\begin{tabular}{|l|l|l|l|l|l|l|l|l|l|}
\hline Year & 2006 & 2007 & 2008 & 2009 & 2010 & 2011 & 2012 & 2013 & 2014 \\
\hline $\begin{array}{l}\text { Indicator for } \\
\text { consumer } \\
\text { confidence }\end{array}$ & $-29,1$ & $-31,1$ & $-34,4$ & $-31,7$ & $-36,6$ & $-49,6$ & $-46,2$ & $-41,0$ & $-42,9$ \\
\hline
\end{tabular}

Source: NSI, Consumer Survey 2004-2014

Apparently, low consumer confidence can be analyzed as a function of inherently different factors, including: the expectations of the financial condition of households; the expectations on the general economic development of the country; inflation expectations. These conditions determine and are indicative of the tendency of increasing the nominal quantity of savings of non-financial entities, households and non-profit organizations in different maturity deposit products, including current accounts. Only for the period 09.2011-12.2012, the number of deposits is increased by 314023 or 5312411 million BGN. Bank loans also start to increase but at a much slower pace than deposits - by 15062 or 2165623 million BGN as absolute value.

The process of obtaining a bank loan has been significantly hampered by the considerable decline of investments which lead to a number of negative consequences: asset depreciation; large scale decapitalization of companies; tangible decrease of the value of available collateral.

Table 2. Company costs for acquisition of fixed assets in the period 2004- 2014 (mln BGN)

\begin{tabular}{|c|c|c|c|c|c|}
\hline 2008 & 2009 & 2010 & 2011 & 2012 & 2013 \\
\hline 29424 & 21274 & 16218 & 17913 & 19091 & 18089 \\
\hline
\end{tabular}

Source: NSI, Costs for acquisition of fixed assets

The data covering the period 2008-2013 shows that the amount of companies costs for acquisition of fixed assets remain low (Table 2). The reason can be sought both in the reduced domestic consumption and the conservative credit policy of the banks which increased their down payment requirements in project financing. The price of the credit resource required by the banks in providing loan capital is also worth mentioning. As shown in Table 3, the average price of both BGN and EUR loans remains high for the period 2007-2012. The impact of such interest policy may be summarized as follows:

- High interest rates have an aggravating effect on businesses with regard to obtaining new and restructuring already received loans that are reviewed and approved at adjusted interest rates. It is an additional restriction of the business activity that shrinks the profit rate of companies.

- The demand of loan capital is directly dependent on interest rates, hence, potential borrowers employ a passive, wait-and-see 
YOSIFOV T., et al.

position in both seeking capital and fixed asset investment.

- The high price of loans has an "erosive" effect on the relations between businesses and banks. On one hand, businesses become passive and incredulous to the banks, on the other hand, banks themselves restrict the possibilities of implementing successful investment projects in an effort to fully cover market risks.

Table 3. Average effective interest rate, new business loans for non-financial enterprises for the period 2007-2012

\begin{tabular}{|c|c|c|}
\hline Period & BGN (up to $1 \mathrm{mln}$ BGN) & EURO (up to $1 \mathrm{mln}$ Euro) \\
\hline 2007 & 8,98 & 8,10 \\
\hline 2008 & 10,44 & 8,61 \\
\hline 2009 & 10,18 & 8,66 \\
\hline 2010 & 9,18 & 8,37 \\
\hline 2011 & 8,52 & 8,72 \\
\hline 2012 & 8,43 & 8,19 \\
\hline
\end{tabular}

Source: BNB, interest rates and volumes, new business loans for non-financial enterprises

It is necessary to underline the fact that there is a positive tendency with regard to the financial results generated by the bank sector. Bank profits are an important indicator with direct correlation on the level of trust in bank institutions. As evident from Table 4, the net profit of banks in Bulgaria in 2014 has been increased by $43.29 \%$ in comparison to 2013 .
This points to the confidence in the country's bank sector regardless of the disequilibrium conditions on the market in the summer of 2014. In addition, it is a signal of the ability of banks in finding ways to manage their activity successfully in the conditions of reduced demand of loan capital.

Table 4. Net profit of banks for the period 2013-2014

\begin{tabular}{|c|c|c|c|}
\hline $\begin{array}{c}\text { Amount of assets in } \\
2013 \text { ('000 BGN.) }\end{array}$ & $\begin{array}{c}\text { Amount of assets in 2014 } \\
\text { ('000 BGN.) }\end{array}$ & $\begin{array}{c}\text { Change } \\
\text { ('000 BGN.) }\end{array}$ & Change (\%) \\
\hline 513762 & 746313 & 232551 & 45,29 \\
\hline
\end{tabular}

Source: Author's calculations based on data of BNB

The assets of the banks sector also follow a tendency of increase. Figure 1 shows that for the period $2004-2012$ the ratio of bank assets to GDP is rising and by the end of the said period it is $106 \% .23$ of GDP. These data reaffirm the significance of the bank sector for the economic development and its contribution to the growth of GDP in particular.

$\square$ assets/GDP

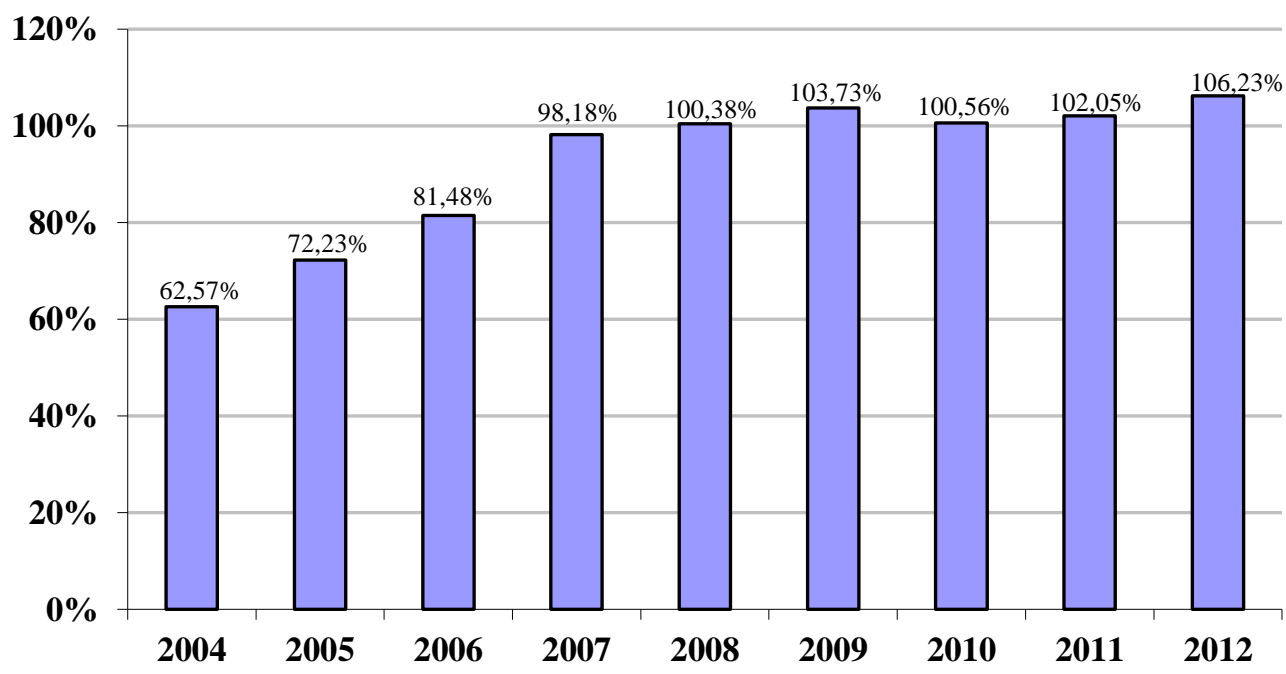

Figure 1. Correlation of bank assets to GDP of the country for the period 2004 - 2012 Source: BNB, NSI 
YOSIFOV T., et al.

At this stage, one part of the objective realities connected with the activity of the banks in the country has been outlined as an immediate aftereffect of the reduced confidence, hence the relationship between banks and their customers.

The purpose of this research paper is not limited solely to the localization of a part of the problems arising from the low amount of trust in the country. It aims at providing specific recommendations for efficient improvement of this relationship such as wider use of product bank innovations both in terms of credit and deposit products.

\section{Product bank innovation as a factor for increasing the confidence in bank institutions.}

The concept of product innovation has a complex, ambiguous connotation. Some authors identify it to innovations in general. For instance, P. Doyle determination of innovations is "creating and providing goods and services that bring the customers benefits perceived as new or superior." (1). Certainly, this is justified in view of the decisive role of product innovations in innovation processes. A deeper look into the understanding of the nature of innovation processes reveals that their midpoint is exactly the development of new products. Also, any other process requires, to a greater or lesser extent, using new products - complementary equipment for new ways of management; raw materials, provisions, etc. for introducing new technologies which, in turn, provide the development of new products.

Generally, marketing-related references define product innovation as developing and providing new products or improving/modifying the existing ones.

The following definitions reflect this tendency:

- ,...process of identifying innovative unmet customer wants and embedding new technologies in unique new product features" (4);

- „... a process of developing and launching a new product on the market" (1);

- „...organized, systematic and rationalized work on creating and introducing new products.." (2)

The interpretation of product innovation set out in the innovation bill (which, since 2011 never came into effect) is also similar, namely (6) "product innovation" is the introduction of a new or significantly improved product and/or service. The product innovation is considered to be introduced if it has reached to the consumer market. Small changes or improvements to products/services with insignificant level of novelty is not considered to be product innovations; increasing the volume of finished products; ceasing the production of an existing product; changes resulting only from price modifications; custom products; regular seasonal or other cyclic product changes; diversification of the range of products by introducing insignificant changes. It is worth noting that from the perspective and in view of its practical value, the formulation of product innovation refers to innovations also perceived from the point of view of the market and the business organization.

From the point of view of the market, there is a three level differentiation (in an ascending order depending on the relation: advent of the new product - consumer habits):

- Products with lowest level of novelty, i.e. products which do not significantly change consumer habits

- New products that significantly change consumer habits

- New products that create new consumer habits

From the perspective of the business organization - producer, products are considered to be new if they are:

- Imitations (pseudo-innovations) - already familiar products produced by other companies from the same industry sector in the country or elsewhere in the world which have not been produced in the relevant company until now;

- Improved existing products/modifications;

- Improved imitations;

- Radical (paramount, revolutionary) innovations - products which are produced for the first time in the company and for the first time appear on the market. These products have highest level of novelty and change/create new consumer habits.

By inference, we can already draw a draft definition of product bank innovation: a process of introducing new bank products which satisfy to a higher extent the consumer needs in comparison to other competitive alternatives. What is more, the innovation activity of banks should be viewed as an integral part of the mission, vision and values of every bank institution.

The role of product innovations, however, is not limited solely by achieving higher efficiency coefficient of the bank activity. Product innovations enhance the quality of bank service, widens the product range mix, improve the technological process, etc. (Figure 2). 


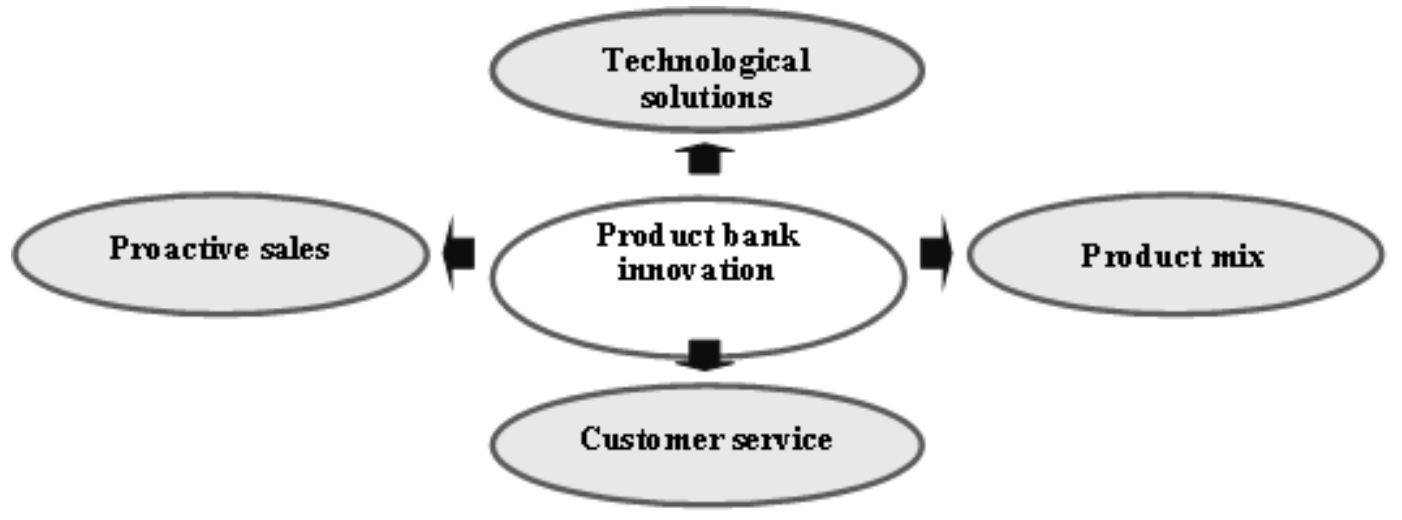

Figure 2. Importance of product innovations for bank activity

Product innovations provide independence and flexibility, leaving price competition between banks on the back burner for a non-price battle focused on gaining customer trust through creating products of higher consumer value additional bonuses (for holders of debit and credit cards); free insurance packages; preferences for shopping in a selection of commercial establishments; travelling to foreign countries, etc. At the same time, it should be noted that one of the essential features of product innovations is their comparatively short life cycle and impossibility of copy protection.

Bulgarian scientific bibliography lacks works about product innovations in the bank sector. Neither there is empirical evidence on the importance of product bank innovation for consumer confidence.

The results from a recent survey on the innovation niches and tendencies in the interaction between business organizations and banks show that: (3) The interaction of business organizations with banks needs innovative solutions for a more comprehensive interaction and efficiency in conducting their operation.

- There are significant in number and turnover capacity innovation niches which can enhance the efficiency of interaction, making it beneficial and advantageous for both parties.

- Due to the conservative approach and the slow-motion innovation progress banks take no advantage of the emerging innovation niches.

- Due to the large market share and the few competitors in the bank segment, a large part of potential opportunities and niches for innovations remain unfulfilled.

The prevailing share of product innovations in the bank sector in Bulgaria is held by the imitation type, improved existing products/modifications and improved imitations, while the radical innovations are estimated to be with low rate of introduction.

Examples of product innovations over the recent years are listed below:

- Mobile banking - direct 24/7 access to customer accounts via mobile device. Special service first launched by UniCredit Bulbank in 2011. One year later, First Investment Bank in collaboration with $\mathrm{M}$ tel launch a pilot project for a mobile contactless payment through Near Field Communication (NFC technology). In 2013, DSK Bank introduced DSK Gameo a gamification mobile application using the principles of gaming to incetivise customer to make regular savings.

- Debit and credit cards for contactless payments, already in 2010. First Investment bank together with MasterCard launched a new generation bank cards for instant payment (PayPass) by tapping to POS devices. Most banks quickly adopted this innovation in card payment and start to replace their POS terminal infrastructure with new devices. 2014 is marked by the immense growth of contactless plastics (according to UniCredit Bulbank data, sales increase by nearly $28 \%$ as against 2013). Among the banks that issued these type of cards are UniCredit Bulbank, CIBANK, DSK BANK, CKB, etc.

- On-line banking - online banking is mass world scale service, yet comparatively new to the Bulgarian bank experience. UniCredit Bulbank pioneered with this innovation early in 1999 as home/office banking.

- Overdraft for narrow customer groups product innovation focused on different market segments - doctors, dentists, pharmaceutists, university students. Leaders in the introduction of this product innovation are Postbank and ProCredit Bank. 
YOSIFOV T., et al.

\section{REFERENCES}

1. Балева В. Продуктьт. Маркетингови стратегии и политики, УИ “Стопанство”, C., 2007.

2. Банчев П. Маркетингови продуктови решения (стратегически аспекти), СА „Д. А. Ценов”, Свищов, 1997.

3. Йорданова 3. Иновационен модел за разширяване взаимодействието между бизнеса и банките (автореферат), София, 2015.

4. Shaoming Z., H. Fu. International Marketing: Emerging Markets, Emerald, 2011
5. Stiglitz, J. Guided by an Invisible Hand. Business, 2008.

6. Проект на Закон за иновациите, $<$ http://www.mi.government.bg/files/userup loads/files/vop/inovation.pdf >, (01.05.2015).

7. НСИ, Наблюдение на потребителите.

8. НСИ, Разходи за придобиване на ДМА.

9. БНБ, Лихвени проценти и обеми по нов бизнес по кредити за сектори нефинансови предприятия. 